\title{
FURTHER INFORMATION ON THE AVIFAUNA OF ST. MATTHEW AND HALL ISLANDS, BERING SEA, ALASKA
}

BRYCE W. ROBINSON, 615 E. Krall St., Boise, Idaho 83712; bryce@ornithologi.com JACK J. WITHROW, University of Alaska Museum, 907 Yukon Drive, Fairbanks, Alaska 99775-6960

RACHEL M. RICHARDSON, STEVEN M. MATSUOKA, and ROBERT E. GILL, JR., U. S. Geological Survey, Alaska Science Center, 4210 University Drive, Anchorage, Alaska 99508

ANDREW S. JOHNSON and IRBY J. LOVETTE, Cornell Lab of Ornithology, 159 Sapsucker Woods Road, Ithaca, New York 14850

JAMES A. JOHNSON, U. S. Fish and Wildlife Service, Division of Migratory Bird Management, 1011 East Tudor Road, Anchorage, Alaska 99503

ANTHONY R. DEGANGE, P.O. Box 671264, Chugiak, Alaska 99567

MARC D. ROMANO, U. S. Fish and Wildlife Service, Alaska Maritime National Wildlife Refuge, Homer, Alaska 99603

ABSTRACT: In June and July 2018 and July 2019 we surveyed birds on St. Matthew and Hall islands, isolated in the central Bering Sea. Our surveys were focused on the McKay's Bunting (Plectrophenax hyperboreus), Rock Sandpiper (Calidris ptilocnemis ptilocnemis), and Pelagic Cormorant (Phalacrocorax pelagicus) but encompassed all birds and yielded 13 species and four subspecies new to the islands' avifaunal list, and new details and documentation of breeding for eight species. Especially notable discoveries include a mixed pair of Bewick's (Cygnus columbianus bewickii) and Whistling (C. c. columbianus) Swans, a mixed pair of the Glaucous-winged (Larus glaucescens) and an Asian subspecies of the Herring Gull (L. argentatus vegae), and discovery of a colony of $\sim 100$ pairs of the Red-legged Kittiwake (Rissa brevirostris). Also, contrary to many previous expeditions, we found the Gray-crowned Rosy-Finch (Leucosticte tephrocotis umbrina) to be common and conclude that it may be resident.

The St. Matthew Island group, including St. Matthew, Hall, and Pinnacle islands, is located in the central Bering Sea $\left(60^{\circ} 24^{\prime} \mathrm{N}, 172^{\circ} 42^{\prime} \mathrm{W}\right.$; Figure 1), and is part of the Alaska Maritime National Wildlife Refuge (see Winker et al. 2002 for physical descriptions of the islands and details of their habitats). 


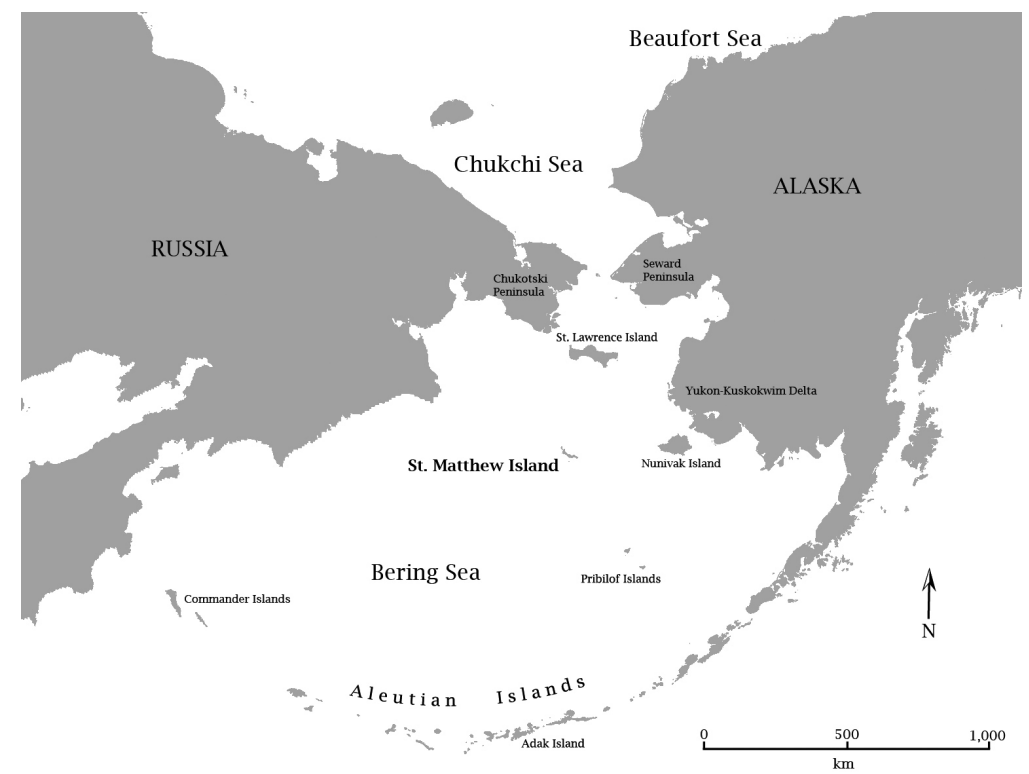

Figure 1. St. Matthew Island and the greater Beringian region, with annotated locations mentioned in the text.

The islands host a unique mixture of Beringian, Asian, and North American avifauna (Winker et al. 2002) -including the entire breeding population of the McKay's Bunting (Plectrophenax hyperboreus; Matsuoka and Johnson 2008 ) and $80 \%$ of the population of the nominate subspecies of the Rock Sandpiper (Calidris ptilocnemis ptilocnemis; Ruthrauff et al. 2012). Despite the distinctiveness of their avifauna, since the end of the $19^{\text {th }}$ century these remote and uninhabited islands have been visited by ornithologists infrequently, owing largely to their isolation. Winker et al. (2002) reviewed the avifaunal accounts from the sporadic and usually brief scientific visits to St. Matthew Island through the $20^{\text {th }}$ century and provided an annotated list of the 125 bird species observed: 31 breeding, eight possibly breeding, and 86 passage migrants. They concluded that (p. 506) "we have yet to determine the complete breeding avifauna" and "have only scratched the surface of the subject of migrations." Johnson et al. (2004) updated this list with 11 new species observed from late May to early July 2003 during their systematic line-transect surveys for breeding Rock Sandpipers and McKay's Buntings across St. Matthew and Hall islands (Matsuoka and Johnson 2008, Ruthrauff et al. 2012) and their study of McKay's Buntings nesting on St. Matthew Island (Johnson et al. 2013).

Here we add 13 species and four subspecies (including clarifications) to the avifaunal list for St. Matthew and Hall islands, provide new details and documentation of breeding for eight species, and discuss several other notable observations. We made these observations from 6 June to 7 July 2018 when we revisited both islands to replicate the aforementioned line-transect surveys 
and nesting studies aimed at monitoring the global populations of McKay's Bunting and the nominate subspecies of the Rock Sandpiper and to collect bird specimens for the University of Alaska Museum. From 6 to 11 June, eight people conducted line-transect surveys regularly spaced across both islands $(1.5 \mathrm{~km}$ and $0.5 \mathrm{~km}$ apart for St. Matthew and Hall islands, respectively). From 12 June to 7 July, five people remained on the northern end of St. Matthew Island near Bull Seal Point (“Camp 1983" in Johnson et al. 2013; Figure 2) to continue surveys and study the nesting of the buntings and sandpipers. Our nest searching and monitoring were concentrated within $3 \mathrm{~km}$ of camp (Figure 2), with only occasional forays beyond that (e.g., to North Lake). From 6 to 14 June, bird specimens were collected at three locations on St. Matthew Island and on Hall Island. In 2019, we returned to St. Matthew and Hall islands from 23 to 31 July to survey the islands by boat for the Pelagic Cormorant (Phalacrocorax pelagicus) and to assess the status of breeding of

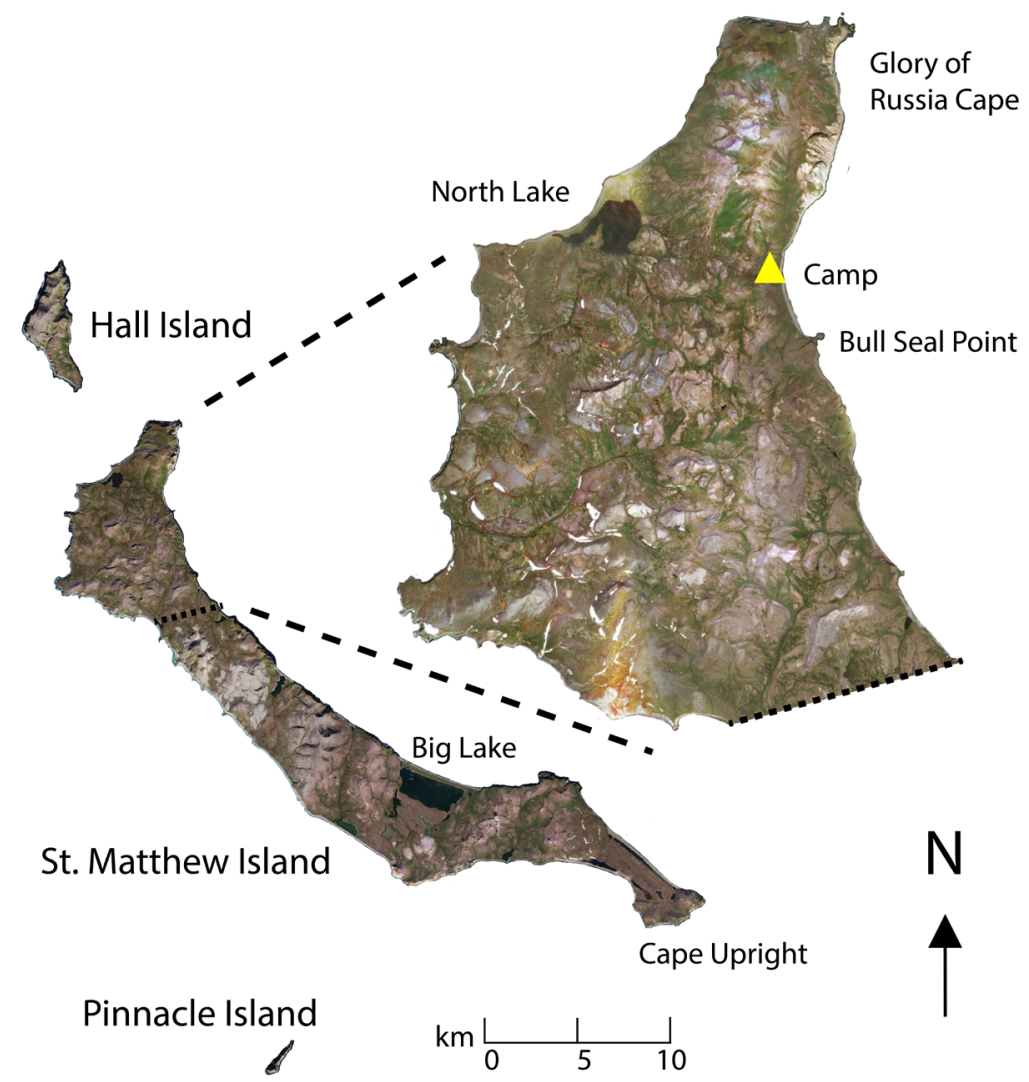

FIgure 2. St. Matthew, Hall, and Pinnacle islands, showing the study area during our visit in 2018, and points of reference discussed in the text. 
the Red-legged Kittiwake (Rissa brevirostris). With a three- or four-person crew, we circumnavigated all three islands of the St. Matthew Archipelago (St. Matthew, Hall, and Pinnacle) in a 4.9-m inflatable boat.

In the following accounts, subspecies nomenclature follows Gibson and Withrow (2015), and status and abundance terms follow Kessel and Gibson (1978). We list subspecies parenthetically in the absence of specimens when we identified them by photographs or inferred them from geographic range. We bracket species that we did not substantiate by photograph or specimen. We also revise some species' breeding status (informed by the North American Ornithological Atlas Committee's guidelines; www.bsc-eoc.org/norac/ atlascodes.htm) if our observations expand on information in Winker et al. (2002) and Johnson et al. (2004). We provide references to substantiating materials whenever possible through specimens deposited at the University of Alaska Museum (UAM), in Fairbanks, Alaska, and photos deposited at Cornell University's Macaulay Library (ML; www.macaulaylibrary.org). Unpublished reports or field notes are on file at UAM, at the Alaska Resources and Information Services Library (ARLIS), and/or the responsible institution. Dates of observations were in 2018 unless noted otherwise.

\section{SPECIES ACCOUNTS}

Branta hutchinsii (leucopareia). Cackling Goose. New subspecies. Seven birds were seen on an inland marsh near Big Lake on 6 June (ML 107537951). Notes: The only reports of white-cheeked geese mentioned by Winker et al. (2002) were a flock of 20-30 birds in May and a flock of four in July, both in 1982. The subspecies was not noted, but in 1982 the population of leucopareia was only a few thousand birds (see Byrd 1998), although a single bird resembling leucopareia was reported from St. Paul Island that year (Gibson 1982). Since its recovery (see Mini et al. 2011), the Aleutian Cackling Goose has been observed annually on the Pribilof Islands, (e.g., Tobish 2014) and may have reached St. Lawrence Island as well (see photos in Lehman 2019). Both B. h. taverneri and minima nest as near as the Seward Peninsula and Yukon-Kuskokwim delta, respectively (Gibson and Kessel 1997, Gibson and Withrow 2015).

Cygnus columbianus (columbianus and bewickii). Tundra Swan. First confirmed nesting and new subspecies. Two nests of C. c. columbianus, one found on 7 June (UAM 43110) and the other on 17 June (ML 114828061), each with four eggs. On

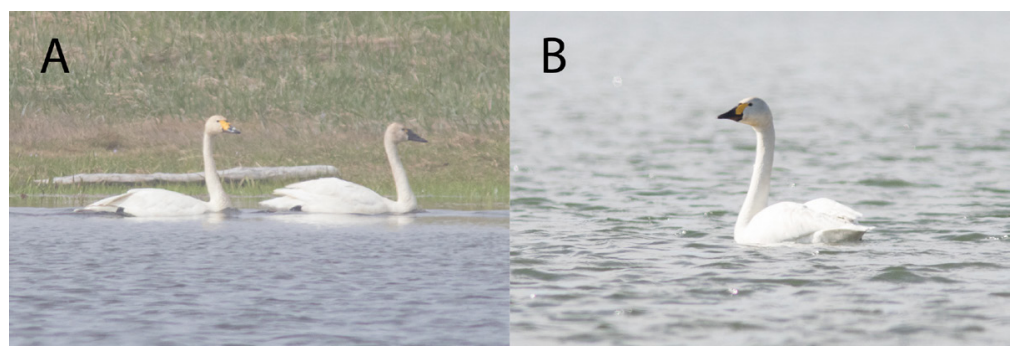

Figure 3. Mixed pair of Tundra Swans (A; bewickii left, columbianus right) observed 12 June 2018 at "North Lake," and (B) a lone example of subspecies bewickii observed 6 June 2018 near "Big Lake," St. Matthew Island, Bering Sea, Alaska. 
12 June we also observed a mixed pair (breeding status unknown) comprising one C. c. bewickii and one C. c. cvolumbianus (Figure 3A; ML 107541481), and on 6 June a swan with the bill approximately 30\% yellow (Figure 3B; ML 154853691), an amount well within the description of C. c. bewickii (Evans and Sladen 1980). Throughout our stay on the island we observed multiple pairs and small groups of nominate columbianus daily, with a high count of 10 on 19 June. Notes: Almost all Tundra Swans observed in the eastern Aleutians, Pribilof Islands, St. Matthew Island, and St. Lawrence Island have been C. c. columbianus (see Preble and McAtee 1923, Gabrielson and Lincoln 1959, Fay and Cade 1959, Fay 1961, Winker et al. 2002). Birds with significant yellow in the bill, identified as C.c. bewickii, have been reported several times, usually in late May or early June, in the western and central Aleutians (Gibson and Withrow 2015, Tobish 2015a), the Pribilof Islands (Tobish 2006a, 2015a, b), at King Salmon (Tobish and Isleib 1992, Tobish 2015a), and at least once from St. Lawrence Island (Lehman 2019). Mixed pairs of bewickii and nominate columbianus have been observed in the northern part of the Chukotski Peninsula (Kondratiev 1991, Arkhipov et al. 2013), and the C. c. columbianus phenotype has apparently expanded west there recently (Syroechkovski 2002).

Anas acuta. Northern Pintail. First confirmed nesting. Nest with eight eggs on 6 June. Notes: Klein (1959) listed the species as breeding without providing details. The Northern Pintail nests in small or moderate numbers on St. Lawrence Island (Fay and Cade 1959, Lehman 2019) and the Pribilof Islands (S. Schuette, in litt., 2019).

Anas crecca (crecca and carolinensis). Green-winged Teal. First confirmed nesting. Two nests with nine eggs both found on the north end of the island, 17 June (ML 115708501) and 21 June. We were unable to determine the subspecies of either nesting female, but we found that among males A. c. carolinensis (nine individuals) outnumbered A. c. crecca (four). Notes: Nominate crecca predominates in the Pribilof Islands (e.g., Gabrielson and Lincoln 1959, DeCicco 2008; UAM unpublished data and specimens), where intergrades are seen regularly, and the species is known to breed (Preble and McAtee 1923). Subspecies carolinensis outnumbers A. c. crecca on St. Lawrence Island, where there is only one breeding record for the species (Lehman 2019).

Antigone canadensis canadensis. Sandhill Crane. First confirmed nesting. One nest with one egg found 16 June (ML115710441, ML115710451). We observed small numbers regularly throughout our time on the island, in pairs and in flocks numbering up to 17 individuals (Hall Island, 12 June). One specimen: UAM 41976, adult o", 12 June, Hall Island. Notes: The species is a regular migrant across the Bering Strait to and from Russia (Krapu and Brandt 2008), a regular spring migrant on the Pribilof Islands (S. Schuette, in litt., 2019), and breeds on St. Lawrence Island (Lehman 2019).

Pluvialis fulva. Pacific Golden-Plover. Probable breeder. A pair, the male in flight display, was seen on 6 June, and a single bird was heard on 7 June, all near Big Lake. A single bird was heard 11, 12, and 14 June, and a pair was seen on 16 and 19 June, all near North Lake. We observed the pair near North Lake behaving as if nesting, giving alarm calls and acting defensively toward a nearby Dunlin (Calidris alpina) and Western Sandpiper (Calidris mauri). Although we searched extensively throughout the area, we did not find a nest. Notes: The Pacific Golden-Plover breeds in western Alaska and Russia, and uncommonly on St. Lawrence Island (Lehman 2019) and Nunivak (Johnson et al. 2019). It is a common migrant on the Pribilof Islands (S. Schuette, in litt., 2019) and the Aleutians (Gibson and Byrd 2007).

Charadrius hiaticula (tundrae). Common Ringed Plover. Newly documented species. One female seen 11-12 June (ML107540781). Notes: In the absence of photo or specimen substantiation, Winker et al. (2002) treated several reports of single birds, as well as a report of a nest with two eggs, in June 1982 as hypothetical. The 
species is a rare to uncommon spring migrant and breeder on St. Lawrence Island (Lehman 2019) and a casual fall migrant on the Pribilof Islands (S. Schuette, in litt., 2019). We regularly encountered Semipalmated Plovers (C. semipalmatus) exhibiting breeding behavior (UAM 41905-41909).

[Bartramia longicauda. Upland Sandpiper. New species. A single individual seen 16 June (BWR), but not photographed. Notes: Only one other accepted Bering Sea report, from St. Paul Island, 31 May 2002 (Tobish 2002), although there is an undocumented report of two birds from St. Lawrence Island (see Lehman 2019).]

[Calidris canutus (roselaari). Red Knot. New species. A flock of four individuals seen in flight on 7 June (REG) but not photographed. Notes: The Red Knot is a casual spring migrant in the Aleutians and St. Lawrence Island (Kessel and Gibson 1978, Gibson and Byrd 2007) and a rare migrant on the Pribilof Islands (S. Schuette, in litt., 2019). Many thousands of this species stop over at the Yukon-Kuskokwim delta each spring (Gill and Handel 1990).]

Calidris alpina (pacifica). Dunlin. Probable breeder. We observed individuals on five days between 11 and 26 June (high count seven on 23 June). These included a pair copulating on 12 June and one performing distraction displays indicating brood defense on 23 June. Notes: From their plumage characteristics and range, we presume that these birds are C. a. pacifica rather than C. a. arcticola (REG; P. Tomkovich, in litt., 2019). The Dunlin breeds on the Chukotski Peninsula and throughout western mainland Alaska south to the Alaska Peninsula (Warnock and Gill 1996). It is an uncommon spring and fall migrant on the Pribilof Islands (S. Schuette, in litt., 2019), and a common breeder on St. Lawrence Island, where the subspecies is uncertain, although C. a. pacifica is the most likely (Lehman 2019).

Calidris mauri. Western Sandpiper. First confirmed nesting. We observed individuals daily throughout our stay, with a high count of 20 and a nest with four eggs on 6 June. Five specimens (UAM 41901-41904) included females with collapsed follicles, birds with incubation patches, and a pair from Hall Island. Notes: Winker et al. (2002:498) described this species as an uncommon migrant and breeder, with "small numbers $(<5)$ seen during most summers," but saw no evidence of nesting beyond distraction displays. The species breeds in mainland western Alaska and at a few locations on the Chukotski Peninsula (Franks et al. 2014), breeds commonly on St. Lawrence Island (Lehman 2019), and is an uncommon spring and common fall migrant on the Pribilof Islands (S. Schuette, in litt., 2019).

Gallinago gallinago (gallinago). Common Snipe. Newly documented species. We observed one or two individuals winnowing 10-16, 21, and 24 June (ML 107539621). Notes: Winker et al. (2002) did not distinguish the Common and Wilson's snipe because neither species was substantiated by specimen. Although Johnson et al. (2004) did not mention it, both species were observed winnowing in 2003 (D. Ruthrauff, in litt., 2019).

[Gallinago delicata. Wilson's Snipe. New species. We observed multiple individuals (high count of three on 12 June) winnowing 7-12 June. Notes: Both G. gallinago and $G$. delicata reach the central Aleutians (Gibson and Byrd 2007), the Pribilof Islands as uncommon migrants with one record of successful breeding ( $G$. delicata; S. Schuette, in litt., 2019), and St. Lawrence Island as rare migrants (Lehman 2019).]

Xenus cinereus. Terek Sandpiper. New species. A single individual seen 6 June (UAM 41702, adult $\%$ ), and a single individual performing a flight display on 8 June. Notes: The Terek Sandpiper is casual or intermittent in the western Aleutians, in the Pribilof Islands, and at St. Lawrence Island (Kessel and Gibson 1978, Gibson and Byrd 2007, Lehman 2019).

Tringa nebularia. Common Greenshank. New species. A single individual seen 26 


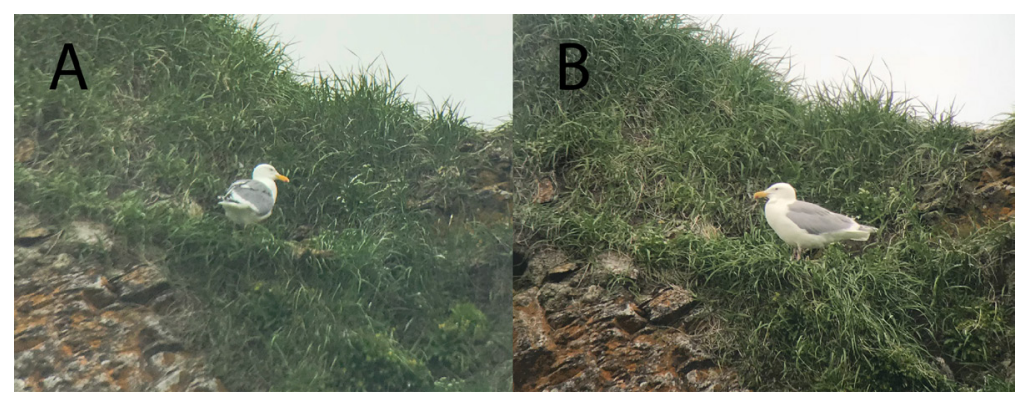

Figure 4. Mixed pair of gulls (A, Larus argentatus vegae; ML189498441) and (B, L. glaucescens; ML189497661) attending at least one nestling at Bull Seal Point, St. Matthew Island, Bering Sea, Alaska, 30 June-2 July 2018. This pair was observed together at the nest on one occasion, but we were unable to obtain a photograph.

June (ML 107547201, ML107547211). Notes: A rare spring migrant in the western Aleutians, in the Pribilof Islands, and at St. Lawrence Island (Kessel and Gibson 1978, Gibson and Byrd 2007).

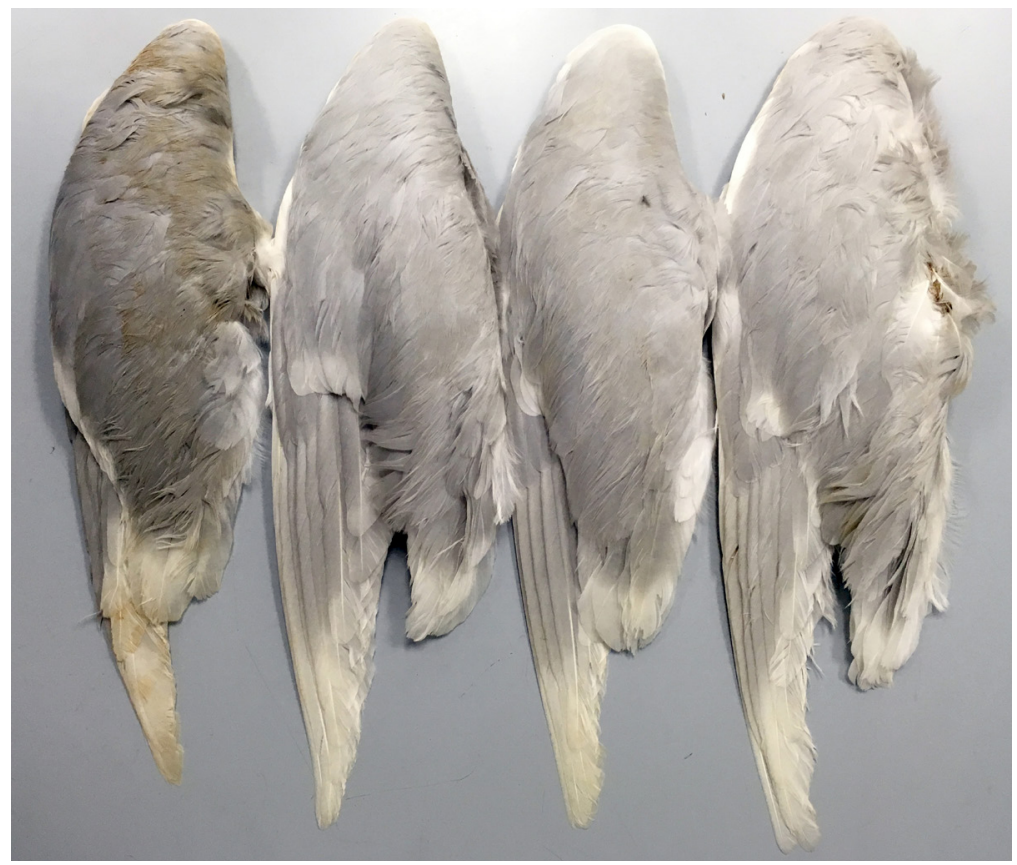

FIGURE 5. Wings of Larus hyperboreus salvaged from St. Matthew Island in early June 2018. The left-most wing (UAM 41662), smaller and darker than the others, is likely an example of $L$. h. barrovianus and not $L$. h. pallidissimus, represented here from left to right by UAM 41658, 41660, and 41661. 
Stercorarius parasiticus. Parasitic Jaeger. First confirmed nesting. We found a two-egg nest attended by a pair of light-morph birds on 6 June (UAM 41646, UAM 41647). Another pair, also of the light morph, defended a territory on 19 June, but we were unable to find a nest. Notes: "Pairs" of Parasitic Jaegers have been observed before on St. Matthew (DeGange and Sowls 1978), but they were not previously known to breed on the island (Winker et al. 2002). Parasitic Jaegers are regular and widespread breeders on the Yukon-Kuskokwim delta and Nunivak Island (e.g., Gabrielson and Lincoln 1959), and have bred at least once on St. Lawrence Island (Sauer and Urban 1964), where their breeding status is not well understood (Lehman 2019), but are not known to nest on the Pribilof Islands. Almost all birds breeding in the Aleutian Islands are of the dark morph (Gibson and Byrd 2007).

Rissa brevirostris. Red-legged Kittiwake. First confirmed breeding. We observed $\sim 200$ individuals occupying sea cliffs on the northwest side of St. Matthew Island on 19 June, 1 , 4, and 6 July (at $60^{\circ} 29^{\prime} \mathrm{N}, 173^{\circ} 3^{\prime} \mathrm{W}$; Robinson et al. 2019). Birds were seen in courtship displays, carrying nest materials, and nest building, indicative of at least attempted nesting. From 23 to 31 July 2019 we observed 260 individuals attending cliffs in the same locations as observations in 2018, with $~ 100$ nests containing small or medium-sized nestlings. Notes: Previously this species was considered casual or accidental during summer on St. Matthew (Winker et al. 2002). Nearly all of the world's Red-legged Kittiwakes breed at four main sites, the majority in the Pribilof Islands (Byrd et al. 1997). Only a few smaller colonies are known elsewhere (Gibson and Byrd 2007, Robinson et al. 2019).

Rhodostethia rosea. Ross's Gull. New species. One individual was on Hall Island on 9 June (UAM 41541, second-year $\left.0^{7}\right)$. Notes: Ross's Gulls are encountered regularly as fall migrants in the Chukchi and Beaufort seas (Divoky et al. 1988, Maftei et al. 2014), but their wintering areas are not well understood and they appear to be only very rare in Alaska south of the Bering Strait (e.g., Kenyon and Phillips 1965, Kessel and Gibson 1978, Tobish 1997, Gibson and Byrd 2007, Lehman 2019).

Larus gulls. New information. In July 1997 Winker et al (2002) found that nearly $50 \%$ of the large white-headed gulls on St. Matthew were Glaucous-winged (Larus glaucescens) and predicted their numbers would increase (Winker et al. 2002). In contrast, in 2018 we found Glaucous Gulls (L. hyperboreus) far outnumbering Glaucous-winged Gulls (e.g., high count of 11 Glaucous-winged with 50 Glaucous Gulls on 28 June). Of the 11 observable nesting pairs of Larus at Bull Seal Point 30 June-2 July, seven were of Glaucous Gulls, three were of Glaucous-winged Gulls, and one was a mixed pair, a Glaucous-winged with a Herring Gull (L. argentatus vegae; see below). In 1983, there were 19 Glaucous Gull and at least three Glaucous-winged Gull nests visible at Bull Seal Point (B. E. Lawhead, unpubl. data).

The mixed Glaucous-winged $\times$ Herring Gull pair was attending at least one downy young (Figure 4; ML189497661, ML189498441). Additional Herring Gulls (also presumed to be vegae) observed include an adult that "long-called" to a Glaucous Gull while both rested together on the ocean behind the R/V Tighla $\hat{x}$ on 5 June, $9 \mathrm{~km}$ west of Cape Upright; an immature bird on Hall Island on 10 June (L. a. vegae, UAM 41648, $3^{\text {rd }}$ cycle $0^{7}$ ); and adults on the north end of St. Matthew on 15, 19, 28, and 30 June, and 2-4 July (high counts of four on 30 June and 4 July). Subspecies vegae is a regular breeder on St. Lawrence Island (Fay and Cade 1959, Stephensen et al. 1998, Lehman 2019). Although L. a. vegae has been inferred to hybridize with the Glaucous-winged Gull on the basis of phenotypes of birds observed in Japan (fide Malling Olsen and Larsson 2003), we are unaware of any other documentation for such a pairing. A bird collected in the Pribilof Islands 5 August 1948 might be the product of such a pairing (USNM 396014; Kenyon and Phillips 1965), in part because the Pribilof Islands lie much farther west than the areas of substantial hybridization between the Glaucous-winged Gull and L. a. smithsonianus, in the northern Gulf 
of Alaska (Williamson and Peyton 1963, Patten 1974, 1980, Patten and Weisbrod 1974, Patten and Patten 1976, 1983, DeCicco et al. 2017).

We tentatively interpret a salvaged Glaucous Gull wing that is darker and significantly smaller than the others to represent subspecies barrovianus (UAM 41662, inferred $\%$ [wing chord $420 \mathrm{~mm}$ ]), when compared with five salvaged wings (UAM 41658-41661) and one breeding pair (UAM 41663, 41664) of L. h. pallidissimus (see Malling Olsen and Larsson 2003; Figure 5).

Gavia arctica (viridigularis). Arctic Loon. Newly documented species. One seen offshore near Bull Seal Point 27-30 June (ML107548221). Notes: Winker et al. (2002) assessed G. arctica or G. pacifica (Pacific Loon) as rare in spring and summer. Gavia arctica is a rare migrant in the western and central Aleutians (Gibson and Byrd 2007), casual in the Pribilof Islands where most are observed in mid-June (e.g., Preble and McAtee 1923, Schuette, in litt., 2019), and uncommon in spring on St. Lawrence Island (Lehman 2019).

Pandion haliaetus (ssp.). Osprey. New species. One probable female observed intermittently 9-24 June (ML107539381). Our photographs are inadequate for subspecific identification (see, e.g., Strandberg 2013). Notes: Gibson and Byrd (2007) discussed as hypothetical a half-dozen reports of this species from the Aleutian Islands without substantiating specimen or photo. The Osprey is casual in the Pribilof Islands (e.g., Sladen 1966, Tobish 2015b) and at St. Lawrence Island (Gibson et al. 1987, Lehman 2019); it has occurred at least once on the Chukotski Peninsula (Arkhipov et al. 2013). The subspecies of these birds is unknown. Some, particularly from the western Aleutians and Chukotka, might represent nominate haliaetus (see Hartert 1920), but most others in the Bering Sea region are probably of North American origin since this long-distance migrant nests as close as the Yukon-Kuskokwim delta (Mindell 1983).

Haliaeetus leucocephalus. Bald Eagle. New species. A first-cycle bird was seen 6 June (ML 183399941). Notes: The Bald Eagle is rare in the Pribilof Islands (S. Schuette, in litt., 2019) and casual or accidental on St. Lawrence Island (Lehman 2019).

Sayornis saya yukonensis. Say's Phoebe. New species. One on Hall Island 10 June (UAM 41500, adult o'?). Notes: The first Bering Sea record of this species was from St. Lawrence Island, 10 June 2005 (Lehman 2019), and there have been two fall records at St. Paul Island (Tobish 2006b, 2012).

Corvus corax principalis. Common Raven. Newly documented subspecies. Seen regularly throughout our stay on St. Matthew and Hall islands (high count of seven on 6 June). Notes: Hanna (1917) inferred that the ravens he observed were of this subspecies, but an adult female (UAM 41600, with incubation patch) collected on Hall Island on 13 June 2018 is the first specimen we are aware of. The comparatively small size of this bird ( $1250 \mathrm{~g}$, wing chord $431 \mathrm{~mm}$, bill length [nares to tip] $46.4 \mathrm{~mm}$ ) indicates that St. Matthew Island ravens are not part of the large kamtschaticus from southwest Alaska and the Aleutian Islands (see Rea 1986). Ravens do not breed in the Pribilof Islands (Hanna 1917, Kenyon and Phillips 1965), where they are only intermittent visitors, but nest regularly at St. Lawrence Island (Fay and Cade 1959, Lehman 2019).

Phylloscopus examinandus. Kamchatka Leaf Warbler. New information. Three males taken on Hall Island, two on 9 June and one on 10 June, had sequences of cytochrome oxidase subunit 1 (CO1) matching this Old-World taxon (UAM 4163941641; GenBank accession numbers MK659560-65960-65962; Alström et al. 2011). Sequencing was done by Life Scanner (Guelph, Ontario). Notes: Identification to species of Arctic Warblers (sensu lato) is difficult without specimens; the only previous specimen from St. Matthew is also P. examinandus (Withrow et al. 2016). There 
is one spring report of a purported P. examinandus for St. Paul Island (S. Schuette, in litt., 2019), where P. borealis is the most common Old World warbler with some spring records in mid-June but most records in fall. At St. Lawrence Island, spring (generally early June) records of Arctic Warblers represent P. borealis (Lehman 2019).

Leucosticte tephrocotis umbrina. Gray-crowned Rosy-Finch. New information. We found rosy-finches to be common, with birds seen daily throughout our stay with daily high counts of 50+ on the southern third of Hall Island, 9-13 June, and 25 on northern St. Matthew Island on 14 June. This is consistent with the description of them as "common... in proper habitat...usually seen in groups," during summer 1982 (B. E. Lawhead unpubl. data), but contrasts with the low numbers observed during other visits. For example, only one bird was seen by F. L. Beals (on 11 July), after nearly constant exploring since his arrival of 30 June 1944 (unpubl. notes available from Alaska Resources Library and Information Services, Anchorage); 27 birds total from 15 July to 9 August 1957 despite walking nearly the entire island (Klein 1959); five in $16 \mathrm{~km}, 22$ July 1997 (K. Winker unpubl. data).

In a contemporary series of male rosy-finches collected from St. Paul (27 May-1 June 2018) and St. Matthew islands (6-9 June 2018), the St. Matthew birds are slightly longer winged and heavier, but females are similar in size and weight (Table 1). The St. Matthew Island birds approach the size of L. t. "maxima" from the Commander Islands (Ridgway 1901, Brooks 1915, Hellmayr 1938, Murie 1944, but cf. Vaurie 1956), a similarly isolated population, usually synonymized with griseonucha (Hellmayr 1938, Vaurie 1959). This conformance with Bergmann's rule suggests that the St. Matthew breeding population may well be isolated from other rosy-finches.

There is evidence to suggest that St. Matthew rosy-finches are nonmigratory residents (cf. Winker et al. 2002). For instance, other populations of large graycheeked rosy-finches (subspecies umbrina or griseonucha) in the Bering Sea region are effectively nonmigratory, and neither is known north of St. Matthew and Nunivak islands, despite considerable ornithological work in surrounding areas. The apparently lower numbers of rosy-finches in winter on the Pribilof Islands (Preble and McAtee 1923) might reflect partial migration and/or dispersal, population attrition, flocking, and/or weather and observer bias. These low numbers suggest, at minimum, that the Pribilof Islands do not see a winter influx of birds from St. Matthew Island. Farther south, winter banding data from Cold Bay (Bailey 1974) suggests no influx of rosy-finches at that location either. We have seen no specimen of umbrina taken from beyond the Pribilof or St. Matthew islands, despite opportunities for such discovery. For example, a specimen of $L$. $t$. littoralis (UAM 2891) was taken from rosy-finches being banded at Adak Island in the central Aleutians in December 1974. The sole St. Lawrence Island record of this species is based on a June 1988 specimen of L. t. tephrocotis (Lehman 2019). We interpret the absence

TABLE 1 Wing Lengths and Masses of Gray-crowned Rosy-Finches Collected on St. Matthew and St. Paul Islands, Alaska, 27 May-1 June $2018^{a}$

\begin{tabular}{lcccc}
\hline Sex & Variable & St. Matthew & & St. Paul \\
& & $P^{d}$ \\
\hline Male & Wing length & $120.1(116.0-124.6)$ & $117.1(112.3-122.9)$ & 0.023 \\
& Mass & $47.1(43.5-54.5)$ & $44.1(39.0-47.5)$ & 0.008 \\
Female & Wing length & $111.1(108.6-114.7)$ & $110.8(108.7-111.9)$ & 0.763 \\
& Mass & $49.6(47.0-57.0)$ & $47.3(43.0-50.5)$ & 0.231 \\
\hline
\end{tabular}

${ }^{a}$ Means of unflattened wing $(\mathrm{mm})$ and mass $(\mathrm{g})$, with ranges in parentheses, of UAM 4183741876.

${ }^{b} n=14$ males, 6 females.

${ }^{c} n=12$ males, 8 females.

${ }^{d}$ Results two-tailed $t$-tests between means with variances assumed to be equal. 
of extralimital reports of umbrina, the lack of migration in other closely related populations, the distinct if slight geographic variation, and the apparent dramatic population fluctuations (possibly due to low winter survival of a small population occupying marginal winter habitat) as evidence that the population on St. Matthew Island is nonmigratory.

Plectrophenax nivalis. Snow Bunting. Newly documented species. On 4 July, one very worn female (ML 107598001) was foraging near a female McKay's Bunting, which on one occasion chased it away. We did not observe evidence of breeding. Although small numbers of Snow Buntings have been reported in previous years (Winker et al. 2002, Matsuoka and Johnson 2008), we are unaware of any other archived photos.

Zonotrichia atricapilla. Golden-crowned Sparrow. New species. A single individual was present 6 June (UAM 41638, adult $\sigma^{7}$ ). Notes: This species is an intermittent spring and regular fall visitant in the Pribilof Islands (S. Schuette, in litt., 2019) and a casual spring and regular fall migrant on St. Lawrence Island (Lehman 2019).

\section{ACKNOWLEDGMENTS}

Without the support of the Alaska Maritime National Wildlife Refuge, in particular captain John Faris and crew of the R/V Tighlâx, this work would not have been possible. G. Vernon Byrd, Daniel D. Gibson, Paul E. Lehman, and Daniel R. Ruthrauff provided thorough reviews that greatly improved the manuscript. The findings and conclusions in this article are those of the authors and do not necessarily represent the views of the U. S. Fish and Wildlife Service. Any use of trade, firm or product names is for descriptive purposes only and does not imply endorsement by the U.S. government.

\section{LITERATURE CITED}

Alström, P., Saitoh, T., Williams, D., Nishiumi, I., Shigeta, Y., Ueda, K., Irestedt, M., Björklund, M., and Olsson, U. 2011. The Arctic Warbler Phylloscopus borealis-three anciently separated cryptic species revealed. Ibis 153:395-410; doi. org/10.1111/j.1474-919X.2011.01116.x.

Arkhipov, V. Yu., Noah, T., Koschkar, S., and Kondrashov, F. A. 2013. Birds of Mys Shmidta, north Chukotka, Russia. Forktail 29:91-96.

Bailey, E. P. 1974. Winter banding of passerines on the Alaska Peninsula. Bird Banding 45:307-314; doi.org/10.2307/4512070.

Brooks, W. S. 1915. Notes on birds from east Siberia and arctic Alaska. Bull. Mus. Comp. Zool. 59:361-413.

Byrd, G. V. 1998. Current breeding status of the Aleutian Canada Goose, a recovering endangered species, in Biology and management of Canada Geese (D. H. Rusch, M. D. Samuel, D. D. Humburg, and B. D. Sullivan, eds.), pp. 21-28. Proc. Int. Canada Goose Symp., Milwaukee.

Byrd, G. V., Williams, J. C., Artyukhin, Yu. B., and Vyatkin, P. S. 1997. Trends in populations of Red-legged Kittiwake Rissa brevirostris, a Bering Sea endemic. Bird Cons. Int. 7:167-180; doi.org/10.1017/S0959270900001489.

DeCicco, L. 2008. Wildlife observations at St. Paul Island, Alaska in 2008. U.S. Fish and Wildlife Service Rep. AMNWR 08/20, Alaska Maritime National Wildlife Refuge, Homer, AK.

DeCicco, L. H., Gibson, D. D., Tobish, T. G. Jr., Heinl, S. C., Hajdukovich, N. R., Johnson, J. A., and Wright, C. W. 2017. Birds of Middleton Island, a unique landfall for migrants in the Gulf of Alaska. W. Birds 48:214-293; doi.org/10.21199/WB48.4.1.

DeGange, A. R., and Sowls, A. L. 1978. A faunal reconnaissance of the Bering Sea 
National Wildlife Refuge 26 June-27 July, 1977. Field Rep. 77-039, U.S. Fish and Wildlife Service, Anchorage.

Divoky, G. J., Sanger, G. A., Hatch, S. A., and Haney, J. C. 1988. Fall migration of Ross' Gull (Rhodostethia rosea) in Alaskan Chukchi and Beaufort seas. Final report, OCS Study MMS 88-0023, Alaska Fish and Wildlife Research Center, Anchorage.

Evans, M. E., and Sladen, W. J. L. 1980. A comparative analysis of the bill markings of Whistling and Bewick's Swans and out-of-range occurrences of the two taxa. Auk 97:697-703.

Fay, F. H. 1961. The distribution of waterfowl to St. Lawrence Island, Alaska. Annu. Rep. Wildfowl Trust 12:70-80.

Fay, F. H., and Cade, T. J. 1959. An ecological analysis of the avifauna of St. Lawrence Island, Alaska. Univ. Calif. Publ. Zool. 63:73-150.

Franks, S., Lank, D. B., and Wilson, W. H. Jr. 2014. Western Sandpiper (Calidris mauri), version 2.0, in The Birds of North America (A. F. Poole, ed.), no. 90. Cornell Lab Ornithol., Ithaca, NY; doi.org/10.2173/bna.90.

Gabrielson, I. N., and Lincoln, F. C. 1959. The Birds of Alaska. Stackpole, Harrisburg, PA.

Gibson, D. D. 1982. Alaska region (summer 1982). Am. Birds 36:1007-1009.

Gibson, D. D., and Byrd, G. V. 2007. Birds of the Aleutian Islands, Alaska. Nuttall Ornithol. Club and Am. Ornithol. Union Ser. Ornithol. 1.

Gibson, D. D., and Kessel, B. 1997. Inventory of the species and subspecies of Alaska birds. W. Birds 28: 45-95.

Gibson, D. D., and Withrow, J. J. 2015. Inventory of species and subspecies of Alaska birds, second edition. W. Birds 46:94-185.

Gibson, D. D., Tobish, T. G. Jr., and Isleib, M. E. 1987. Alaska region (summer 1987). Am. Birds 41:1475-1477.

Gill, R. E. Jr., and Handel, C. M. 1990. The importance of subarctic intertidal habitats to shorebirds: A study of the central Yukon-Kuskokwim delta, Alaska. Condor 92:709-725; doi.org/10.2307/1368690.

Hanna, G. D. 1917. The summer birds of the St. Matthew Island Bird Reservation. Auk 34:403-410; doi.org/10.2307/4072266.

Hartert, E. 1920. The birds of the Commander Islands. Novitates Zoologicae 27:128-158; doi.org/10.5962/bhl.part.7307.

Hellmayr, C. E. 1938. Catalogue of birds of the Americas. Zool. Ser. Field Mus. 13, part XI.

Johnson, J. A., Matsuoka, S. M., Ruthrauff, D. R., Litzow, M. A., and Dementyev, M. N. 2004. Additions to the avifauna of St. Matthew Island, Bering Sea. W. Birds 35:50-52.

Johnson, J. A., DeCicco, L. H., Matsuoka, S. M., and Sowls, A. L. 2013. Nesting ecology of McKay's Buntings on St. Matthew Island, Alaska. Wilson J. Ornithol. 125:376-384; doi.org/10.1676/12-139.1.

Johnson, O. W., Connors, P. G., and Pyle P. 2019. Pacific Golden-Plover (Pluvialis fulva), version 3.1, in The Birds of North America (P. G. Rodewald, ed.). Cornell Lab Ornithol., Ithaca, NY; doi.org/10.2173/bna.pagplo.03.1.

Kenyon, K. W., and Phillips, R. E. 1965. Birds from the Pribilof Islands and vicinity. Auk 82:624-635; doi.org/10.2307/4083224.

Kessel, B., and Gibson, D. D. 1978. Status and distribution of Alaska birds. Studies Avian Biol. 1.

Klein, D. R. 1959. Saint Matthew Island reindeer-range study. U. S. Fish and Wildlife Service Spec. Sci. Rep.-Wildlife 43.

Kondratiev, A. Ya. 1991. The distribution and status of Bewick's Swans Cygnus bewickii, Tundra Swans C. columbianus and Whooper Swans C. cygnus in the 'Extreme Northeast' of the USSR. Wildfowl Suppl. 1:56-61. 
Krapu, G. L., and Brandt, D. A. 2008. Spring migratory habits and breeding distribution of Lesser Sandhill Cranes that winter in west-central New Mexico and Arizona. N. Am. Crane Workshop Proc. 10:43-49.

Lehman, P. E. 2019. The Birds of Gambell and St. Lawrence Island, Alaska. Studies of Western Birds 4. W. Field Ornithol., Camarillo, CA.

Maftei, M., Davis, S. E., Uher-Koch, B. D., Gesmundo, C., Suydam, R., and Mallory, M. L. 2014. Quantifying fall migration of Ross's Gulls (Rhodostethia rosea) past Point Barrow, Alaska. Polar Biol. 37:1705-1710; doi.org/10.1007/s00300014-1552-4.

Malling Olsen, K., and Larsson, H. 2003. Gulls of Europe, Asia, and North America. Christopher Helm, London.

Matsuoka, S. M., and Johnson, J. A. 2008. Using a multimodel approach to estimate the population size of McKay's Buntings. Condor 110:371-376; doi.org/10.1525/ cond.2008.8492.

Mindell, D. P. 1983. Nesting raptors in southwestern Alaska; status, distribution, and aspects of biology. BLM-Alaska Tech. Rep. 8, Bureau of Land Mgmt., Anchorage.

Mini, A. E., Bachman, D. C., Cocke, J., Griggs, K. M., Spragens, K. A., and Black, J. M. 2011. Recovery of the Aleutian Cackling Goose Branta hutchinsii leucopareia: 10-year review and future prospects. Wildfowl 61:3-29.

Murie, O. J. 1944. Two new subspecies of birds from Alaska. Condor 46:121-123; doi.org/10.2307/1364278.

Patten, S. M. Jr. 1974. Breeding ecology of the Glaucous-winged Gull in Glacier Bay, Alaska. M.S. thesis, Univ. Wash., Seattle.

Patten, S. M. Jr. 1980. Interbreeding and evolution in the Larus glaucescens-Larus argentatus complex on the south coast of Alaska. Ph.D. thesis, Johns Hopkins Univ., Baltimore.

Patten, S. M. Jr., and Patten, L. R. 1976. Breeding ecology of the Gulf of Alaska Herring Gull group (Larus argentatus \& Larus glaucescens), in Principal Investigators' Reports, Environmental Assessment of the Alaskan Continental Shelf, vol. 2., pp. 271-368. Natl. Ocean. Atmos. Admin. and Bureau Land Mgmt., Boulder, CO.

Patten, S. [M.] Jr., and Patten, L. R. 1983. Evolution, pathobiology, and breeding ecology of large gulls (Larus) in the northeast Gulf of Alaska and effects of petroleum exposure on the breeding ecology of gulls and kittiwakes, in Final Reports of Principal Investigators, Environmental Assessment of the Alaskan Continental Shelf, Biological Sciences, vol. 18, pp. 1-352. Natl. Ocean. Atmos. Admin. and Bureau Land Mgmt., Juneau.

Patten, S. M. Jr., and Weisbrod, A. R. 1974. Sympatry and interbreeding of Herring and Glaucous-winged Gulls in southeastern Alaska. Condor 76:343-344; doi. org/10.2307/1366351.

Preble, E. A., and McAtee, W. L. 1923. A biological survey of the Pribilof Islands, Alaska. N. Am. Fauna 46; doi.org/10.3996/nafa.46.0001.

Rea, A. M. 1986. Corvus corax. Geographic variation, in The Known Birds of North and Middle America (A. R. Phillips, ed.), part I, pp. 65-66. A. R. Phillips, Denver.

Ridgway, R. 1901. The birds of North and Middle America. Bull. U.S. Natl. Mus. 50 , part I.

Robinson, B. W., Johnson, A. S., Lovette, I. J., and Romano, M. D. 2019. Potential northward expansion of breeding range of Red-legged Kittiwake Rissa brevirostris. Marine Ornithol. 47:229-234.

Ruthrauff, D. R., Tibbitts, T. L., Gill, R. E. Jr., Dementyev, M. N., and Handel, C. M. 2012. Small population size of the Pribilof Rock Sandpiper confirmed through distance-sampling surveys in Alaska. Condor 114:544-551; doi.org/10.1525/ cond.2012.110109. 
Sauer, E. G. F., and Urban, E. K. 1964. Bird notes from St. Lawrence Island, Alaska. Bonner Zool. Beiträge 15:45-58.

Sladen, W. J. L. 1966. Additions to the avifauna of the Pribilof Islands, Alaska, including five species new to North America. Auk 83:130-135; doi. org/10.2307/4082987.

Stephensen, S. W., Pungowiyi, C., and Mendenhall, V. M. 1998. A seabird survey of Saint Lawrence Island, Alaska, 1996-1997. U. S. Fish and Wildlife Service, Anchorage.

Strandberg, R. 2013. Ageing, sexing and subspecific identification of Osprey, and two WP records of American Osprey. Dutch Birding 35:69-87.

Syroechkovski, E. E. Jr. 2002. Distribution and population estimates for swans in the Siberian Arctic in the 1990s, in Proceedings of the Fourth International Swan Symposium, 2001 (E. C. Rees, S. L. Earnst, and J. Coulson, eds.), pp. 100-113. Waterbirds 25, Spec. Publ. 1.

Tobish, T. G. Jr. 1997. Alaska region (spring 1997). Natl. Audubon Soc. Field Notes 51:910-912.

Tobish, T. [G. Jr.]. 2002. Alaska region (spring 2002). N. Am. Birds 56:343-345.

Tobish T. [G. Jr.]. 2006a. Alaska region (summer 2005). N. Am. Birds 60:564-567.

Tobish, T. [G. Jr.]. 2006b. Alaska region (fall 2005). N. Am. Birds 60:119-123.

Tobish, T. [G. Jr.]. 2012. Alaska region (fall 2011). N. Am. Birds 66:146-152.

Tobish, T. [G. Jr.]. 2014. Alaska region (summer 2013). N. Am. Birds 67:638-641.

Tobish, T. [G. Jr.]. 2015a. Alaska region (spring 2014). N. Am. Birds 68:413-415.

Tobish, T. [G. Jr.]. 2015b. Alaska region (summer 2014). N. Am. Birds 68:542-544.

Tobish, T. G. Jr., and Isleib, M. E. 1992. Alaska region (spring 1992). Am. Birds 46:462-465.

Vaurie, C. 1956. Systematic notes on Palearctic birds. No. 20. Fringillidae: The genera Leucosticte, Rhodopechys, Carpodacus, Pinicola, Loxia, Uragus, Urocynchramus, and Propyrrhula. Am. Mus. Novitates 1786.

Vaurie, C. 1959. The Birds of the Palearctic Fauna. Passeriformes. H. F. and G. Witherby, London.

Warnock, N. D., and Gill, R. E., Jr. 1996. Dunlin (Calidris alpina), in The Birds of North America (A. F. Poole and F. B. Gill, eds.), no. 203. Acad. Nat. Sci., Philadelphia; doi.org/10.2173/bna.203.

Williamson, F. S. L., and Peyton, L. J. 1963. Interbreeding of Glaucous-winged and Herring Gulls in the Cook Inlet region, Alaska. Condor 65:24-28; doi. org/10.2307/1365135.

Winker, K., Gibson, D. D., Sowls, A. L., Lawhead, B. E., Martin, P. D., Hoberg, E. P., and Causey, D. 2002. The birds of St. Matthew Island, Bering Sea. Wilson Bull. 114:491-509; doi.org/10.1676/0043-5643(2002)114[0491:TBOSMI]2.0.CO;2.

Withrow, J. J., Gibson, D. D., Gerasimov, Y., Gerasimov, N., Shestopalov, A., and Winker, K. 2016. Occurrence and taxonomy of Arctic Warblers (Phylloscopus borealis) sensu lato in North America. Wilson J. Ornithol. 128:268-277; doi. org/10.1676/wils-128-02-268-277.1. 